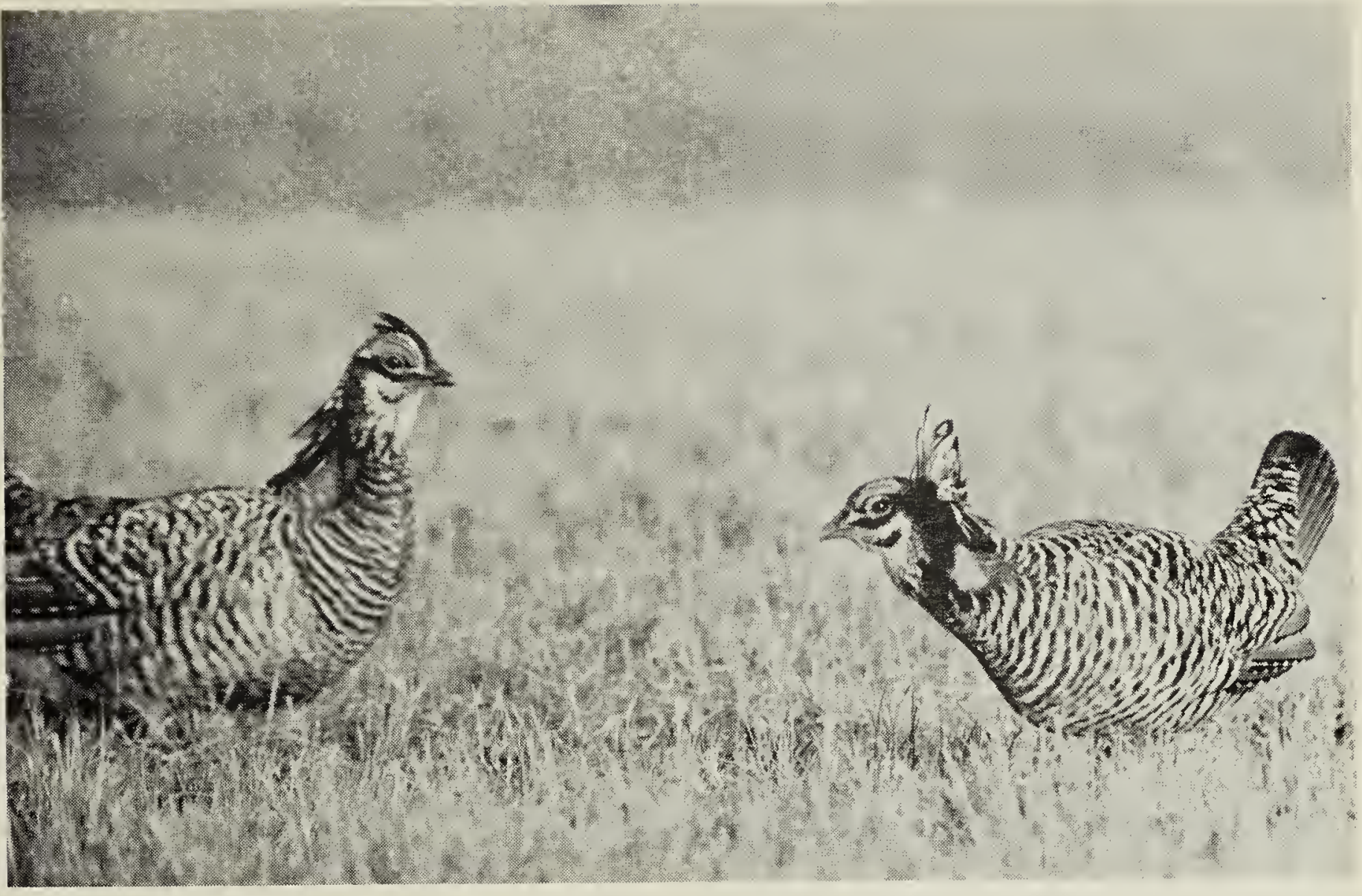

Photo by Miss Kay Hodges, Calgary Greater Prairie Chicken, males sparring on Wisconsin booming grounds

\section{RECORD OF WOOD DUCK AT LITTLE QUILL LAKE}

by Jack C. Shaver, Regina

On August 9, 1965, while I was assisting two students who were banding waterfowl this past summer for the Game Division of the Saskatchewan Department of Natural Resources, we captured an adult male Wood Duck. The trap was located on the south shore of Little Quill Lake (northeast of Watrous). Editor's Note: Another interesting record of the Wood Duck for the summer of 1965 appears in the report of observations in the Saskatoon area, p. 77.

\section{FATAL ENTANGLEMENT OF COMMON TERN}

by C. Stuart Houston, Saskatoon

Bird bander Walter P. Nickell's report on fatal entanglements of Herring Gulls and Common Terns in the Auk, 81:555-556, October, 1964, has prompted me to submit the accompanying photograph. This shows a
Common Tern which died as a result of becoming accidentally entangled in a plant. This adult Common Tern was found in a nesting colony on an island in Redberry Lake, July 28, 1963, hanging by its neck from the fork of a prickly lettuce plant, Lactuca scariola. When we found it, the tern had been dead for several days.

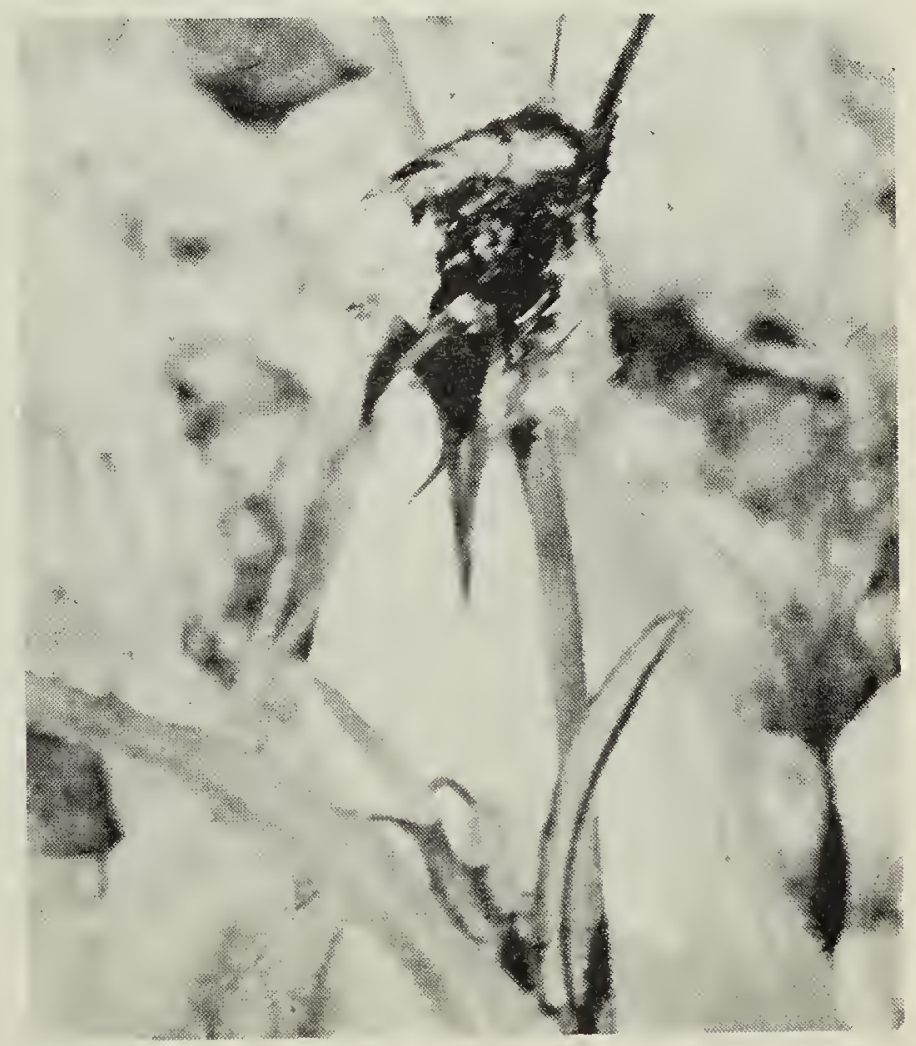

